\title{
Contagion: Does It really Exist or Is It Simply Pseudo Systemic Risk?
}

\author{
Ashley G Frank
}

Graduate School of Business, University of Durban-Westville

\section{ABSTRACT}

Financial market participants seem to have already accepted the phenomena of speculative currency attacks being temporarily correlated, with crises passing "contagiously" from one country to another. Yet doubt still exists about whether speculative attacks on a currency are due to its country's fundamentals or irrespective of them. More conservative economic opinion is that countries with deep mismanagement of national balance sheets and exchange rate policy as well as political irresponsibility, give rise to weaker external positions, from where they suffer higher negative spillover effects. Sadly, despite the possibility of contagious currency crises, being an important policy issue, this paper finds little support by way of systematic empirical analysis. So much so, that the choice is between opting to be a dissident, and, leaving the question unanswered. It chooses the latter.

JEL G10, 15

\section{INTRODUCTION}

In delivering the 1998 David Finch Lecture at the University of Melbourne, the International Monetary Fund's Stanley Fischer offered two main reasons for why there is such growing assent on the view that the international financial system should be reformed (Fischer, 1999), or to put it a bit more crudely why there is such agreement on the need for a new financial architecture (Eichengreen, 1999). The first, as the 1998 East Asian crisis showed us, international capital flows to emerging markets are too volatile, subjecting recipient countries to shocks and crises that are excessively frequent and large. The second, is that there is just too much contagion in the system, a point though advanced during the East Asian crisis that became uncontestable after the Russian devaluation and unilateral debt restructuring spread the crisis across Latin America. It is this second aspect and in particular the question of how it is known that the contagion is excessive, that is difficult to establish. This is particularly because when contagion strikes there is method in the madness, hitting weaker economies harder than stronger ones, so that there it is always 
possible to argue that those countries most affected by contagion "deserved it" more than those that were less affected. Indeed, many economists often argue after a crisis that there was no contagion per se since those countries most badly affected already had major policy or structural weaknesses.

In the wake of the Mexican meltdown, the ability for currency crises to spill contagiously has been hotly debated. Indeed the US\$50 billion of assistance the IMF, the United States and other G-7 governments provided in early 1995 has often been justified by arguing that if the effects of the Mexican crisis were allowed to play itself out, it would have not only been limited to Mexico but would have had serious repercussions for other emerging markets as well. Multilateral intervention was needed because the Mexican authorities had little incentive to internalize such externalities. Supporting this view are the reserve loses, interest-rate increases, and, exchange rate weakening, countries like Argentina and Thailand experienced during the first weeks of 1995. Of course the contrary view would be simply that investors were discriminating in the countries they attacked. Currencies other than the Mexican Peso came under very little pressure, with the effect being felt only in those countries with large current account deficits, over-valued real rates and other weak fundamentals. The implication being that the Mexican bailout, to the extent that it was fuelled by fears of contagion was uncalled for. The 1992/3 crises in the European Monetary System (EMS) was subject to a similar controversy, when it was claimed that the French Franc and the Irish Punt came under attack as a result of the earlier crises of the British Pound and the Italian Lira. In 1993 it was argued that the attack on the French Franc threatened to spill over to other European currencies, the implication being that foreign support for the Franc was essential to prevent chaos from spreading contagiously throughout the EMS. Instead, only those European countries with fundamental weaknesses were subject to speculative attacks. The Netherlands for instance, that appropriately aligned its economic policies to the maintenance of its currency pegs, remained relatively immune. The proposition then became that if contagion did in fact exist, only those countries with particular economic and political circumstances were susceptible, a statement that turns the very definition of contagion on its head. Certainly such a proposition also highlights the role policy may play. Ascertaining whether contagion exists in foreign exchange markets and under what conditions it would inspire currency crises should thus be a high priority for research in open-economy macroeconomics.

The purpose of this paper is to examine the theoretical and empirical literature on crises in foreign exchange markets with an eye towards the prevalence of contagion. Contagion being defined as the co-movement of asset markets not caused by a common movement of fundamentals (Wolf, 1998). Several of the contagion studies that have been conducted are either wholly descriptive of a 
crisis event or use simple correlation coefficients to draw conclusions about transmission effect. Some also control for fundamentals and look at the correlation matrix of the residuals, this as comparing correlation calculations with different sub-samples is an accepted way of studying links among variables. Principal component analysis has also been used. A finding of high correlation has often been advanced as evidence of contagion. Still, as there is no universally accepted definition of the term, different interpretations of this finding have been offered.

High cross-country correlation coefficients may be due to similar fundamentals or to common external shocks, as one would expect in a wide variety of models. Bordo et al. (1995) for instance, found high correlation among stock prices in emerging markets over 1984 to 1995 , but were able to attribute the bulk of it to fundamentals, either through a correlation of in-country fundamentals or a sharing of external fundamentals. They contend that such phenomena should be termed "pseudo systemic risk". Conversely, work by authors such as Calvo (1995) who demonstrated the tequila effect of herding behaviour, suggests that high cross-country correlations are due to investors leaving all emerging markets when a shock hits one of them. Many economists are of the opinion that it is only such simultaneous speculative attacks [or in the language of the market such "bubble-burstings"] that describe true contagion. Thus a suitable research question must be: given the theoretical insights that have been gained, as well as the empirical evidence gathered from the various foreign exchange crisis episodes that have occurred, is it possible to conclude that contagion does actually exist?

This paper, which deals specifically with speculative attacks in foreign exchange markets, is arranged as follows: Section 2 reviews Krugman's (1979) early work on this subject with a view to determining what lessons may be gleaned from his theoretical model building. Section 3 examines the more recent work on multiple equilibria in an attempt to deduce how this phenomenon could help explain speculative bubbles and sun-spot equilibria. Based on this theoretical work Section 4 examines the transmission mechanisms for how foreign exchange crises might spread contagiously. While Section 5 critiques the empirical studies that have been conduced on speculative attacks, to show why the research question remains unanswered. Section 6 concludes by pointing out the way further research should take in order to advance the debate.

\section{KRUGMAN'S MODEL}

The seminal work by Krugman (1979) showed how inconsistencies between domestic economic conditions and an exchange rate commitment inevitably 
leads to the collapse of currency pegs. In his model, the overly expansionary stance of domestic policy caused domestic absorption to exceed production. The difference then spilt over into a balance-of-payments deficit, which the central bank financed by expending reserves. Eventually reserves become so depleted that they fall to a critical threshold that encourages a speculative attack, which in turn depletes the remaining foreign assets. Such reserve depletion necessitates abandonment of the exchange rate peg and following the more expansionary stance of domestic as opposed to foreign policy, the currency depreciates secularly over time.

This balance-of-payments crisis theory produced four classes of insights. First, it helped to identify the relevant fundamentals. Obviously these include the macroeconomic determinants of the exchange rate and the balance of payments, as described by both aggregate models of exchange rate determination as well as the monetary approach to the balance of payments. Given the forward-looking nature of these models, the list of determinants should include the expected values of the relevant series. Indeed, the possibility of multiple equilibria arises because expected future fundamentals can themselves depend on whether a speculative attack occurs. Within this context Meese and Rogoff (1983), Obstfeld and Rogoff (1995) as well as Obstfeld (1995) have pointed to the poor empirical performance of Krugman models, giving concern about the success with which speculative-attack models built on such foundations can be empirically validated.

Second, the Krugman model showed how crises can erupt before official reserves, which decline over time, are actually depleted. Currency speculation occurs through the buying and selling of domestic currency for foreign assets. These transactions come about as traders, wishing to equalize rates of return and balance their portfolios in terms of risk-return trade-offs exchange assets among themselves. When the market is not willing to acquire domestic currency at the prevailing pegged price, a crisis is provoked, leaving the central bank as the counter-party caught short. An incentive thus exits for speculators to liquidate domestic currency holdings despite the central bank having sufficient funds to absorb the volume of sales. The timing of the attack is planned such that its magnitude is just sufficient to eliminate the central bank's reserve stock.

The third implication arising from the model is that a central bank can only maintain a currency peg so long as it has adequate foreign exchange reserves. Once these have been lost in an attack, the peg must be abandoned, there is no other alternative. In the standard model the crisis results in a transition to floating, reserves stocks are then reconstituted and the exchange rate re-pegged. This implication also necessitates an understanding of reserve adequacy. In order that the peg be defended, the central bank must be able to purchase all of 
its liabilities other participants want to redeem. The standard model assumed the volume of such sales would be small, corresponding to the decline in monetary base needed to ratify the fall in money demand that higher interest rates, which follow the shift from pegged to depreciating, bring about. Since domestic residents who require the currency for transaction purposes should continue to hold a significant proportion of that base, such an assumption appeared logical at first. However, as inter alia Edwards (1989) have pointed out, in today's highly Dollarized economies transaction demand for domestic currency may indeed be small, making the share of the monetary base subject to liquidation in a crisis quite significant. On top of that, is the added concern that monetary authorities may also be required to purchase other domestic liabilities (e.g., M2) should the currency crisis initiate a banking crisis as well.

The fourth implication from the Krugman model is that authorities are quite defenseless, having little chance of fending off an attack. Even if the volume of speculative sales of domestic currency was less than the monetary base, the base would still exceed the central bank's net foreign reserve stock (except in the quite uncommon case of a fully backed currency board). Theoretically, the authorities could augment their gross reserves through foreign borrowing, even to the point where reserves exceed the base. Unfortunately if borrowed reserves are used to finance sterilized intervention, the monetary base would increase pari passu with there being no level of gross reserves sufficient to repel an attack. Of course, the attack can be repelled by authorities choosing not to sterilize, but this comes at the cost of a shrinking base and rising interest rates. In that case should a sizable proportion of the base be involved, the resulting interest rate hikes may be so large that, what started as an exchange rate crisis, then leads to a banking crisis. Averting this, forces the central bank into the sterilization it had originally opted against, further undermining its capacity to defend a peg.

\section{MULTIPLE EQUILIBRIA AND SELF-FULFILLING ATTACKS}

Generic to theoretical rational-expectations macroeconomic models is that they have multiple solutions. Standard practice was therefore to assume away divergent solutions by imposing transversality conditions, since most of the solution paths did not converge to a steady state. Recently, however this nonuniqueness property, that allows for multiple equilibria, has become the basis for a body of work on speculative bubbles and sup-spot equilibria. Following a suggestion by Flood and Garber (1984), Obstfeld (1986; 1995), has provided examples of multiple eqilibria and self-fulfilling attacks in foreign exchange markets. These offer an entirely new dimension to thinking about currency crises. 
The possibility of multiple equilibria come about when participants, irrespective of whether current policy is compatible with an indefinite maintenance of a currency peg or not, anticipate that a successful attack will alter policy. In this case it is expected future fundamentals, conditional and absent an attack, rather than current fundamentals, that are incompatible with the peg. Thus two equilibria exist: the first featuring no attack, with no change in fundamentals and indefinite maintenance of the peg. The second, features a speculative attack followed by a change in fundamentals so that the exchange rate-change speculators expected, occurs ex post. Obstfeld (1986) set pre and post crisis policies arbitrarily - if the attack is successful, the government simply adopts a more expansionary policy. It was this arbitrary contingent policy process that was the obvious limitation to his model. In later papers Bensaid and Jeanne (1993), Ozkan and Sutherland (1995) and Obstfeld himself (1995) proposed models of optimizing governments who find it in their self-interest to follow the kind of contingent policy processes that would give rise to multiple equilibria and self-fulfilling attacks. These analyses build on exchange rate escape clauses, where it is optimal for the currency peg to be maintained under certain conditions and abandoned otherwise (c.f., Obstfeld, 1991; De Kock \& Grilli, 1993; Drazen \& Masson, 1994). The behaviour of governments in these models still derives from special utility functions, the literature on multiple equilibria and self-fulfilling attacks being simply examples and special cases.

Krugman (1996) emphasizes this point establishing two further results. The first being that multiple equilibria are ironically less likely when the fundamentals are wrong. This is because when fundamentals are clearly inconsistent with the prevailing currency peg, investors have little doubt that a crisis, as a selfcorrecting device, will occur, hence the model quickly converges to equilibrium as the currency is attacked and devalued. However, when fundamentals are good, multiple equilibria about whether a crisis will eventually result, exist. The second result is that if the authorities preferences are not publicly known the market may test to see its reaction. Thus attacks, that although they are unsuccessful, will result just so that information on authority preferences will be revealed. Models of self-fulfilling attacks imply that good fundamentals may not be enough to avert currency crises. To prevent an attack unjustified by fundamentals, the central bank's credibility must be such that the markets estimate that a relaxation of monetary policy once the peg is abandoned is improbable. Obstfeld (1986) provides such an example, where the risk of a selffulfilling attack is actually eliminated because the central bank reacts to a crisis by implementing a policy that implies exchange rate appreciation. 


\section{HOW CRISES MAY SPREAD CONTAGIOUSLY}

As was stated earlier, very little theoretical work analyzing the conditions under which currency crises spread contagiously has been conducted. Gerlach and Smets (1995) provided the first systematic theoretical treatment of this question. Inspired by the links between the fall of the Finnish Markka in 1992 and the subsequent attack on the Swedish Krona, they considered a two-country model linked together by trade in merchandise and financial assets. In their model, a successful attack on one exchange rate led to its real depreciation, thus enhancing the competitiveness of that country's merchandise exports. This produced a trade deficit in the second country, a gradual decline in its central bank's international reserves and thus ultimately an attack on its currency. The second channel for contagious transmission is the impact of the crisis and depreciation in the first country on the import prices and overall price level in the second. Post-crisis real depreciation in the first reduces import prices in the second. This, in turn, reduces its consumer price index and money demand by its residents. The foreign reserves of the central bank are subsequently depleted by their efforts to swap domestic currency for foreign exchange. By doing this the second country is shifted from a no-attack equilibrium, where, because it has reserves more than sufficient to absorb the volume of prospective sales no grounds exist for a speculative attack, to a second equilibrium where an attack will succeed, giving speculators the incentive to launch it. Andersen (1994) developed a similar argument building on an escape-clause model of exchange rate policy. In his model, a shock from outside the currency market causes the government to abandon its currency peg. Following Barro and Gordon (1983) an exogenous deterioration in domestic competitiveness which increases domestic investment may provide authorities with an incentive to opt for a more expansionary policy in order that unemployment is reduced due to surprise inflation. Andersen uses this reasoning to provide a plausible description of exchange rate policy in Northern Europe in 1991-1992 when the collapse of Soviet trade with the Nordic countries first aggravated unemployment in Finland, leading that government to a more expansionary policy that involved abandoning its peg, subsequently spilling over to the exchange rates of Scandanavia.

Buiter et al. (1996) used an escape-clause model of exchange rate policy to analyse the spread of currency crises in a system of $N+1$ countries, $N$ of which (called the "periphery") peg to the remaining country (the "centre"). The centre is assumed to be more risk averse than the others and hence unwilling to pursue a cooperative monetary policy designed to stabilize exchange rates. A negative shock to the centre leads it to raise interest rates thus inducing the members of the periphery to reconsider their currency-pegging policy. If the members of the periphery cooperate, they may find it in their collective interests to leave the 
system, which would be considered an extreme case of contagion. More commonly, it would be some subset of peripheral countries, primarily those with the least tolerance for high interest rates, who would find it optimal to leave the system under these conditions, thereby limiting the contagion to this subset. As a spin-off their decision to leave actually stabilizes the currency pegs of the remaining members of the system. This comes about because monetary expansion and currency depreciation by some members of the periphery provides the centre country, which would, by then, have an overvalued currency, with the incentive to relax its monetary stance and in so doing relieves the pressure on the remaining members of the periphery. Under this second scenario, contagion is selective: the shock to the centre spilt over negatively to some members of the periphery but positively to others.

Goldfajn and Valdès (1995) focused on the role of illiquidity in financial markets. An important feature of their model was the introduction of financial intermediaries. These authors demonstrated that, in the presence of such intermediaries, small disturbances could provoke large-scale currency runs. This is because intermediaries supply liquid assets to foreigners unwilling to commit to long-term investments; that is, they provide maturity-transformation services. The volume of capital inflow is augmented by their offering attractive terms on liquid deposits. However, when, due to exogenous factors, investors withdraw their deposits, intermediaries unable to costlessly liquidate their assets face the risk of failure. Thus a bank run can produce a self-fulfilling banking crisis (c.f., Diamond \& Dibvig, 1983), just like a currency run can provoke a self fulfilling exchange rate crisis. Further, the run on intermediaries can spill over into a run on the currency as foreign investors withdraw their deposits and convert them into foreign exchange. As investors who experience liquidity problems in one country typically respond by liquidating their positions in other countries, these crises can spread contagiously.

On the subject of information, though not primarily concerned with foreign exchange contagion, Shiller (1995) provides a model in which financial market participants share access to much of the same information (e.g., what appears on Reuters screens) but interpret and process it differently. What they make of the information depends on their own experience, which has been shaped by the local conditions that they faced uniquely. Thus, one market's reaction to a piece of new information may provide a signal about its global implications. It could suggest to traders in other markets how they to should react. The fact that a particular market draws dramatic conclusions from some information may overcome local culture in other markets leading to a revision of expectations (an "information cascade"). Applying this reasoning to speculative attacks, one can see how this effect could lead to an attack on one exchange rate that would prompt traders in other currency markets to attack those exchange rates as well. 
Caplin and Leahy (1994) further this analysis with market participants expecting a crisis but having different priors about its timing. It is costly for traders to take a position in advance of a crisis by moving too early. Each is unsure whether others share his/her belief that the crisis will eventually occur. Whilst they may exchange "cheap talk" amongst themselves they only draw inferences from actual positions taken in the market. The result is "business as usual" with market conditions being normal without a hint of crisis until it suddenly erupts. However, as soon as it occurs, market participants all claim that they had anticipated the crisis and indeed had readied themselves for the eventuality, displaying wisdom after the fact. The utility of this analysis is that it shows how contagion, arising as a crisis in one part of the world, validates individually held suspicions in other markets. Applying this model to the EMS crisis of 19921993 begins by recognizing that there was a widespread belief at the time, that the EMS could not sustain its operations without realignment. Yet because it was extraordinarily stable since January 1987, traders were led to accept the official view that the system could function without further realignments. The political difficulties of ratifying the Maastricht Treaty then trigged the crisis, culminating in the devaluation of the Italian Lira, confirming the belief and revealing to all traders that what they had believed all along about realignments still being necessary, was true.

\section{EMPIRICAL STUDIES OF SPECULATIVE ATTACKS}

Although the literature on crises in foreign exchange markets is full of models suggesting motives for and dynamics of how speculative attacks occur, the process of systematically testing these predictions has barely started. While there may be many convincing studies of currency crises assembled from biased samples of episodes, there is very little that could be termed systematic analysis. There are two main limitations to the studies currently available. It is not only that they consider a selective sample of episodes in which currency pegs collapsed without confirming that the collapses are representative of the underlying population. Rather, and more importantly, most of the episodes where currency pegs were abandoned are themselves inherently unrepresentative of the speculative attack population. Pegs may have been abandoned without a speculative attack; others may even have been repelled. Hence studies like Dornbusch et al. (1995) and Krugman (1996) although being quite informative about the characteristics of the actual episodes they analyse, do not provide a representative characterization of speculative attacks.

The first systematic analysis of currency crises must be Eichengreen et al. (1995) where a measure of speculative attacks was constructed. That measure excluded devaluations and flotations that occurred away from climates of crises 
as well as included unsuccessful attacks. These were then compared with actual devaluations and other exchange rate arrangement changes. The measure of crises was a weighted average of changes in the exchange rate, changes in international reserves available to pay out in response to speculative pressures, as well as changes in the interest rate differential, since interest rates are often used to fend of an attack. These authors findings on the causes and consequences of devaluations and revaluations were all consistent with the predictions of mainstream models. Countries that devalue experience problems of external balance in the period prior to the event. Their trade deficits and reserve loses are associated with relatively expansionary monetary policies. Moreover, the period leading up to devaluation is characterized by problems of internal balance, which show up as high levels of unemployment. And in fact, the expansionary monetary stance of these countries could well have been chosen (at least partly) in response to these domestic concerns. Broadly speaking, revaluations were mirror images of devaluations. In contrast, other foreign exchange market events resisted generalization. For instance, transitions between exchange rate regimes (such as movement from fixed to floating) were found to be largely unpredictable.

Countries whose governments had pursued accommodating monetary policies leading to high inflation and reserve loses, generally in response to deteriorating conditions on the employment front, were more susceptible to crises. The current account moves initially into deficit and the capital account worsens as the crisis nears. Countries that respond quickly by reducing the rate of monetary growth do sometimes succeed in defending the rate. Those retrenching less dramatically may still have to recapitulate but often are able to do so without provoking a major crisis. However, those countries that rely on sterilized intervention to the exclusion of more fundamental policy adjustments are generally unable to avoid a full-blown currency crisis.

Other studies, Moreno (1995) for example, has also followed this approach. He analysed crises in the Pacific Basin economies from 1980 through 1994 and found that periods of speculative pressure tend to be associated with large budget deficits and rapid domestic credit growth rates. He also presented evidence that when slow growth and relatively high inflation make it difficult for authorities to maintain a stable exchange rate, this enhances speculative pressure. However, there was no evidence that external balance indicators differed between crisis and tranquil periods.

Kaminsky and Reinhart (1996) considered speculative attacks on currencies and banking crises, analysing the relationship between the two. They focused on 20 countries in Asia, Europe, Latin America and the Middle East that experienced banking difficulties between 1970-1995. Their index of currency crises was 
constructed as a weighted average of exchange rate changes and reserve changes (as relevant interest rate data was lacking for some countries). In their sample crises tended to be preceded by declining economic activity, weakening export sectors, falling stock markets and high real interest rates. Moreover, crises were also preceded by accelerating money growth and rapid banking system liability growth rates. While banking crises were leading indicators of currency crises, there were few instances where currency crises predicted banking crises.

As stated earlier empirical analysis of contagion is sparse. Mainly the studies that do exist provide informal comparisons of small groups of countries. Burki and Edwards (1995) for instance contrast the experiences of Argentina, Chile and Columbia following the Mexican crisis with those of Chile and Columbia, holding that while contagion was present it was nevertheless selective. Calvo (1996) compares Mexico with other countries in an effort to ascertain why some countries were more susceptible than others to the tequila effect. The econometric model Calvo and Reinhart (1995) built, reported evidence of contagion where capital flows to four small Latin American countries depend not only on the standard determinants but also on a contagion proxy, that being capital flows to four large Latin American countries. As capital flows to neighboring countries are a less-than-ideal proxy and the sample was not randomly selected their results can be questioned.

Schmukler and Frankel (1996) modeled contagion using data on closed-end country funds. Their dependent variable, stock price level, differed from that employed by Eichengreen et al. (1996) who used an indicator variable that took on a value of unity for a speculative attack or zero otherwise, the two are linked in that a rise in domestic interest rates needed to fend off a currency attack should depress equity prices. The Schmukler and Frankel study found evidence that suggested investors differentiated among countries to a greater extent after the 1994 Mexican crisis than after its 1982 predecessor. In the short run a drop in Mexican prices tended to induce sell-offs in other markets motivated by the desire to raise cash. Interestingly, while evidence of contagion in Latin America in the long run was present as well, the long-run effect of a Mexican sell-off on Asian markets was positive.

In the Eichengreen et al. (1996) paper, contagion was thought of as an increase in the probability of a speculative attack on a domestic currency that does not arise from domestic fundamentals such as money or output but from the existence of a (not necessarily successful) speculative attack elsewhere in the world. A panel of quarterly macroeconomic data from twenty industrial countries was analysed from 1959 to 1993. Their measure of speculative pressure was a weighted average of exchange rate changes, reserve changes and interest rate changes. They made use of a binary probit model linking their 
dependent variable to controls with maximum likelihood, including additional regressors to capture the effects of macroeconomic and political influences which affect crisis incidence. Their net was cast quite widely and included the presence of capital controls, electroral victory or defeat of the government, domestic credit growth, inflation, output growth, employment growth, the unemployment rate, the central government surplus/deficit (as a percentage of GDP) and, the current account surplus/deficit (again as a percentage of GDP). Germany was used as the central country. They found that "a speculative attack elsewhere in the world increases the probability of a domestic currency crisis by around 8 percentage points" (emphasis added). The impact of the other regressors was not dramatic, though a few observations are worth noting. For instance, higher inflation and unemployment are associated with increases in the odds of an attack. Still, the absence of robust partial correlations provides grounds for caution against over-interpreting the results. Despite the fact that the authors employed a battery of empirical specifications that failed to reject, at quite high levels of significance, their hypothesis of contagion, their study was unable to distinguish the effects of crises in neighbouring countries from the effects of global shocks. A limitation they acknowledge themselves.

\section{CONCLUSION}

This study set out to answer the question of whether it is possible to conclude that contagion does actually exist. Although the possibility of contagious currency crises is an important issue for policy makers and global investors alike, the question goes right to the heart of the limitations of the existing research. Thus while both theoretical and empirical studies on foreign exchange market crises were appraised and the literature does provide many theoretical models which highlight motives for and dynamics of speculative attacks on pegged currencies as well as the potential channels of transmission, sadly it has found that empirical work lags far behind. While case studies of contagion are available, there seems to be little in the way of systematic empirical analysis. Certainly, not enough to demonstrate convincingly that contagion does really exist.

Epidemiologists would find this situation quite familiar, where they must decided whether the spread of a virus reflects the contagious nature of the germ or the disease-conducive nature of the environment. [South Africans have already had much exposure to this kind of dilemma in the: Does HIV cause AIDS debate?]. Due to the high stakes at risk this paper recommends that the phenomena of weak domestic fundamentals should not be allowed to obscure the existence of contagion. Just because a medical epidemic is more likely to strike those with weaker health, makes it nonetheless an epidemic. And after all, 
history does have a habit, ex post, of looking inevitable. Epidemiologists normally deal with their situations by placing additional structures on the problem. Similarly, further work in this area might be to ask whether countries with close macroeconomic and trade ties are more susceptible to contagion. Currency crises in neighbouring countries could then be weighted by measures of such economic proximity. This approach might better distinguish between what the financial community is already labeling contagion, from what more conservative economists regard simply, as the effects of common unobservable shocks. Till then the question must, at best, remain unanswered.

\section{REFERENCES}

1 ANDERSEN, T. (1994) "Shocks and the viability of a fixed exchange rate commitment", Centre for Economic Policy Research Discussion Paper 969: London.

2 BARRO, R. \& GORDON, D. (1983) "Rules, discretion and reputation in a model of monetary policy", Journal of Monetary Economics, 12: 101122.

3 BENSAID, B. \& JEANNE, O. (1993) The Instability of Fixed Exchange Rate Systems when Raising the Nominal Interest Rate is Costly, Unpublished manuscript, ENPC-CARAS: Paris.

4 BORDO, M.D., MIZRACH, B. \& SCHWARTZ, A.J. (1995) "Real versus pseudo-international systemic risk: Some lessons from history", National Bureau for Economic Research Working Paper, 5371, Cambridge, Mass.

5 BUITER, W., CORSETTI, G. \& PESENTI, P. (1996) Financial Markets and International Monetary Cooperation, Cambridge University Press: Cambridge.

6 BURKI, S. \& EDWARDS, S. (1995) Latin America after Mexico: Quickening the Pace, Unpublished manuscript, World Bank: Washington, D.C.

7 CALVO, G. (1995) "Varieties of capital market crises", Centre for International Economics Working Paper, 16, University of Maryland, College Park.

8 CALVO, G. \& REINHART, C. (1995) Capital inflows to Latin America: Is there Evidence of Contagion Effects, Unpublished manuscript, World Bank \& International Monetary Fund: Washington D.C.

9 CALVO, G. (1996) Capital Flows and Macroeconomic Management: Tequila Lessons, Unpublished manuscript, University of Maryland College Park: Maryland.

10 CAPLIN, A. \& LEAHY, J. (1994) "Business as usual, market crashes and wisdom after the fact", American Economic Review, 84: 548-65. 
11 DE KOCK, G. \& GRILLI, V. (1993) "Fiscal policies and the choice of exchange rate regime", The Economic Journal, 103: 347-56.

12 DIAMOND, D. \& DIBVIG, P. (1983) "Bank runs, deposit insurance and liquidity”, Journal of Political Economy, 91: 401-19.

13 DORNBUSCH, R., GOLDFAJN, I. \& VALDES, R. (1995) "Currency crises and collapses", Brookings Papers on Economic Activity, 2: 219-95.

14 DRAZEN, A. \& MASSON, P.R. (1994) "Credibility of policy versus credibility of policymakers", Quarterly Journal of Economics, 1: 109: 735-54.

15 EDWARDS, S. (1989) Real Exchange Rates, Devaluation and Adjustment: Exchange Rate Policies in Developing Countries, MIT Press: Cambridge, Mass.

16 EICHENGREEN, B., ROSE, A.J., \& WYPLOSZ, C. (1995) "Exchange market mayhem: The antecedents and aftermath of speculative attacks", Economic Policy, 21: 249-312.

17 EICHENGREEN, B., ROSE, A. \& WYPLOSZ, C. (1996) "Contagious currency crises: First tests", Scandanavian Journal of Economics, 98: 463-84.

18 EICHENGREEN, B. (1999) Toward a New International Financial Architecture, Institute for International Economics: Washington, D.C.

19 FISCHER, S. (1999) "Reforming the international financial system", The Economic Journal, 109: F557-F567.

20 FLOOD, R. \& GARBER, P. (1984) "Collapsing exchange rate regimes: Some linear examples", Journal of International Economics, 17: 1-13.

21 GERLACH, S. \& SMETS, F. (1995) "Contagious speculative attacks", European Journal of Political Economy, 11: 45-63.

22 GOLDFAJN, I. \& VALDÈS, R. (1995) Balance of Payments Crises and Capital Flows: The Role of Liquidity, Unpublished manuscript, Michigan: MIT.

23 KAMINSKY, G. \& REINHART, C. (1996) The Twin Crises: The Causes of Banking and Balance-of-Payments Problems, Unpublished manuscript, Federal Reserve Board and International Monetary Fund: Washington, D.C.

24 KRUGMAN, P. (1979) "A model of balance of payments crises", Journal of Money, Credit and Banking, 11: 311-25.

25 KRUGMAN, P. (1996) "Are currency crises self-fulfilling?" in: NBER Macroeconomic Annual, National Bureau for Economic Research: Cambridge, Mass.

26 MEESE, R. \& ROGOFF, K. (1983) "Empirical exchange rate models of the 1970s: Do they fit out of sample?", Journal of International Economics, 14: 3-24.

27 MORENO, R. (1995) "Macroeconomic behavior during periods of speculative pressure or realignment: Evidence from the Pacific Basic 
economies", Economic Review of the Federal Reserve Bank of San Francisco, 3: 3-16.

28 OBSTFELD, M. (1986) "Rational and self-fulfilling balance of payments crises", American Economic Review, 76: 72-81.

29 OBSTFELD, M. (1991) "Destabilizing effects of exchange rate escape clauses", National Bureau for Economic Research, Working Paper, 2603: Cambridge, Mass.

30 OBSTFELD, M. (1995) "International currency experience: New lessons and lessons relearned", Brookings Papers on Economic Activity, 2: 119220.

31 OBSTFELD, M. \& ROGOFF K. (1995) "The intertemporal approach to the current account", In Grossman, K. \& ROGOFF, K. (eds.) Handbook of International Economics, 3, Amsterdam: North-Holland.

32 OZKAN, G. \& SUTHERLAND, A. (1995) "Policy measures to avoid a currency crisis", The Economic Journal, 105: 510-19.

33 SCHUMUKLER, S. \& FRANKEL, J. (1996) Crisis, Contagion and Country Funds, Unpublished manuscript, University of CaliforniaBerkeley, California.

34 SHILLER, R. (1995) "Conversation, information and herd behavior", American Economic Review - Papers and Proceedings, 85: 181-85.

35 WOLF, H.C. (1998) "Determinants of emerging market correlations" in: Levich, R. (ed.) Emerging Market Capital Flows, Kluwer Academic Publishers: London. 